\title{
NEUROCOGNITIVE DYSFUNCTION AFTER CORONARY ARTERY BYPASS SURGERY: A SYSTEMATIC REVIEW
}

Diederik van Dijk, MD

Annemieke M. A. Keizer, MS

Jan C. Diephuis, MD

Catelijne Durand, $\mathrm{MS}^{\mathrm{b}}$

Liesbeth J. Vos, MS ${ }^{b}$

Ron Hijman, $\mathrm{PhD}^{\mathrm{b}}$
Objective: Substantial, albeit scattered, evidence suggests that coronary artery bypass grafting may impair cognitive function. As methods and definitions differ greatly across studies, the reported incidence of cognitive decline after coronary bypass surgery varies widely as well. The aim of the present study was to systematically review those studies on cognitive decline that are relatively comparable and meet with certain quality criteria.

Methods: Four electronic databases and the references of several abstract books and earlier reviews were used to identify relevant literature. Stringent criteria, based in part on the 1994 consensus meeting on assessment of neurobehavioral outcomes after cardiac surgery, were used to assess the studies that were found. In total, 256 different titles were found, of which 23 met with the formulated selection criteria.

Results: Twelve cohort studies and eleven intervention studies were evaluated. A pooled analysis of six highly comparable studies yielded a proportion of $22.5 \%$ (95\% confidence interval, $18.7 \%-26.4 \%$ ) of patients with a cognitive deficit (a decrease of at least 1 standard deviation in at least two of nine or ten tests) 2 months after the operation.

Conclusions: Neurocognitive dysfunction is a frequently occurring complication of coronary artery bypass grafting. The etiologic contribution of cardiopulmonary bypass to this complication will remain unclear until a randomized trial that directly compares off-pump and on-pump bypass surgery is carried out. (J Thorac Cardiovasc Surg 2000;120:632-9)
Co oronary artery bypass grafting $(\mathrm{CABG})$ with the use of cardiopulmonary bypass (CPB) is associated with significant cerebral morbidity. ${ }^{1}$ The two main clinical manifestations of brain injury after $\mathrm{CABG}$ are stroke and cognitive decline. ${ }^{1}$ The incidence of postoperative stroke is consistently reported to be around $3 \%^{1,2}$ and as high as $9 \%$ in patients older than 75 years. ${ }^{3,4}$ However, the reported incidence of cognitive decline varies widely. ${ }^{5}$ This variability is partly caused by methodologic

From the Departments of Anesthesiology a and Psychiatry, ${ }^{\mathrm{b}}$ Utrecht University Hospital, Utrecht, The Netherlands.

Received for publication Feb 29, 2000; revisions requested April 12, 2000; revisions received May 16, 2000; accepted for publication May 16, 2000.

Address for reprints: Diederik van Dijk, MD, Utrecht University Hospital, Department of Anesthesiology, HpN E03-511, PO Box 85500, 3508 GA Utrecht, The Netherlands (E-mail: d.vandijk@anest.azu.nl).

Copyright () 2000 by The American Association for Thoracic Surgery

$0022-5223 / 2000 \$ 12.00+0 \quad \mathbf{1 2 / 1 / 1 0 8 9 0 1}$

doi: $10.1067 / \mathrm{mtc} .2000 .108901$ problems: a multitude of definitions of cognitive decline are used, and a large number of neuropsychologic tests exist to assess the various cognitive domains. ${ }^{6}$ Moreover, the interval between operation and administration of the neuropsychologic tests may range from a few days to several years. Some literature reviews on cognitive deficits after $\mathrm{CPB}$ have been published, ${ }^{7-10}$ but the methodologic variability of the studies hampers comparison of the results.

At a consensus meeting in 1994, several guidelines for the assessment of neuropsychologic deficits after CPB were established. ${ }^{11}$ It was recommended that the neurologic and neuropsychologic state be assessed before the operation to provide accurate baseline information. A second important recommendation was that the analysis should be based on the individual change in performance from baseline to a particular time after the operation. In general, practice effects cause the overall group performance to improve after the operation. Accordingly, when the overall postoperative mean is compared with the preoperative mean, the decline of 
Table I. Literature search: Sources and results

\begin{tabular}{lr}
\hline \multicolumn{1}{c}{ Source } & No. of titles found \\
\hline - MEDLINE electronic database 1980-1999: Medical Subject Heading (MeSH) standard terms: (heart surgery or coronary & 161 \\
artery bypass or extracorporeal circulation or cardiopulmonary bypass; cognition disorders) and (cognitive symptoms or & \\
neuropsychology or neuropsychological tests) & 10 \\
- PsychLit electronic database 1980-1999: standard terms: (heart surgery) and (neuropsychological assessment or cognitive & \\
- assessment or cognition or concentration or attention) & 67 \\
- Book: "Cardiac Surgery and the Brain" by Smith and Taylor ${ }^{12}:$ relevant references of relevant chapters & 69 \\
- relevant references of relevant chapters & 91 \\
- Current Contents and PubMed 1999: January-September & 18 \\
- Total number of different titles & 256 \\
\hline
\end{tabular}

In the numbers of titles found, articles published before 1980 and books are not included.

some individuals is overshadowed by the improvement of others. Also, it was agreed that a late assessment (ideally after 3 months) should be included in the study design, because the patients' performances are unstable in the immediate postoperative period.

Although these consensus guidelines were developed for the design of new research protocols, we found some of them also suitable to interpret studies carried out in the past. This systematic review is restricted to studies on cognitive decline 1 to 12 months after CABG, which were considered methodologically homogeneous according to well-defined and strict criteria. Both the primary selection of studies and the assessment and comparison of the studies that were included were largely based on recommendations of the 1994 consensus. ${ }^{11}$ As a result of the technical improvements of CPB and the alterations in anesthetic management, studies published before 1980 were considered less relevant and therefore were excluded.

\section{Methods}

Literature search. For the literature search, four electronic databases (MEDLINE, PsychLit, PubMed, and Current Contents) and references of four earlier published (abstract) books and three reviews were used. The precise search strategy is described in Table I. To assess the quality of the search strategy, we sampled ten studies that we already had on file and considered relevant. The search strategy was able to identify these articles. The total number of different titles found was 256 (Table I).

Selection of the literature. The studies were independently judged by a clinician and a psychologist using the following selection criteria:

Inclusion criteria:

- Primary research on cognitive decline after CABG, including a preoperative neuropsychologic assessment to provide baseline information
- Postoperative neuropsychologic assessment between 1 and 12 months after the operation

- Data analysis based on the individual change in performance from baseline to a time after the operation

Exclusion criteria:

- Studies published before 1980

- Studies including open chamber or valvular procedures

- Studies with unclear timing of test administration

- Articles describing the same or an overlapping patient sample as other articles already included in the review

These selection criteria were applied on the 256 titles found. Thirty-four articles could be excluded on the basis of the title only and 111 articles were excluded on the basis of the abstract. For the remaining 111 titles, the complete article was studied. The majority of these publications were written in English. Many articles were excluded because data of patients undergoing CABG were mixed with data of patients having valve replacement, because data analysis was based on comparison of mean group performance before and after the operation, or because only an early postoperative neuropsychologic assessment (ie, less than 1 month) was performed. Seven studies were excluded ${ }^{14-20}$ because the same patient series had (partly) been used in other studies already included in the review and their inclusion would have overemphasized the results of these series. Finally, one article published in Japanese was rejected because a translation could not be obtained. Only 23 articles matched all the selection criteria. ${ }^{5,21-42}$

Literature processing. The 23 articles meeting the selection criteria were processed independently by a psychologist and a clinician using a three-page standard form. This form was filled out to systematically assess the research question, study design, neuropsychologic tests used, statistics, main conclusions, and other items. The forms were the basis for Tables II and III in the "Results" section.

The neuropsychologic sections were independently judged by two trained neuropsychologists, blinded for author and journal names. Again, several recommendations of the Statement of Consensus ${ }^{11}$ were taken into account. 
Table II. Cohort studies

\begin{tabular}{|c|c|c|c|c|c|c|c|c|c|}
\hline $\begin{array}{l}\text { First } \\
\text { author }\end{array}$ & $\begin{array}{c}\text { Year of } \\
\text { publication }\end{array}$ & $\begin{array}{l}\text { No. of } \\
\text { patients }\end{array}$ & $\begin{array}{c}\text { Mean } \\
\text { age } \\
(y)\end{array}$ & $\begin{array}{c}\text { NP-test } \\
\text { timing } \\
(\mathrm{mo})\end{array}$ & $\begin{array}{c}\text { Lost to } \\
\text { follow-up } \\
(\%)\end{array}$ & $\begin{array}{c}\text { No. of } \\
\text { tests } \\
\text { used }\end{array}$ & $\begin{array}{l}\text { Definition } \\
\text { of } \\
\text { cognitive } \\
\text { deficit }\end{array}$ & Comparability & $\begin{array}{c}\text { Proportion } \\
\text { of patients } \\
\text { with cognitive } \\
\text { deficit }(\%)\end{array}$ \\
\hline Ellis $^{21}$ & 1980 & 30 & 55 & 1 & 0 & 3 & 7 & - & 17 \\
\hline Shaw $^{22}$ & 1987 & 259 & 54 & 6 & 17 & 10 & 2 & - & 22 \\
\hline Treasure $^{23}$ & 1989 & 76 & 55 & 2 & 12 & 10 & 2 & ++ & 37 \\
\hline Harrison $^{24}$ & 1989 & 78 & 55 & 2 & 40 & 10 & 2 & ++ & 36 \\
\hline Mahanna $^{5}$ & 1996 & 232 & 61 & $1.5 / 6$ & $60 / 61$ & 5 & $7 *$ & - & $14 * / 4 *$ \\
\hline Toner $^{25}$ & 1996 & 61 & 60 & 2 & 0 & 10 & 2 & ++ & 38 \\
\hline Tardiff $^{26}$ & 1997 & 65 & 62 & 1.5 & 12 & 7 & 6 & - & 47 \\
\hline McKhann $^{27}$ & 1997 & 172 & 63 & $1 / 12$ & 26 & 8 & 4 & + & $\dagger$ \\
\hline Braekken $^{28}$ & 1998 & 14 & 64 & 2 & 0 & 10 & 2 & + & 14 \\
\hline Vanninen ${ }^{29}$ & 1998 & 38 & 64 & 3 & 3 & 8 & 3 & - & 22 \\
\hline Browne $^{30}$ & 1999 & 120 & $?$ & 3 & 0 & 2 & $7 \ddagger$ & - & 末 \\
\hline Rasmussen $^{31}$ & 1999 & 35 & 70 & 3 & 17 & 5 & 7 & - & 14 \\
\hline
\end{tabular}

NP-test timing, Time between CABG and postoperative neuropsychologic test administration; Definition of cognitive deficit: 1 ( $\geq 1$ SD in $\geq 1$ test); 2 ( $\geq 1$ SD in $\geq 2$ tests); 3 ( $\geq 1$ SD in $\geq 3$ tests); 4 ( $\geq 0.5$ SD in a domain); 5 ( $\geq 20 \%$ in $\geq 2$ tests); 6 ( $\geq 20 \%$ in $\geq 20 \%$ ); 7 (other); Comparability: ++, tests of "core battery" are used (Rey Auditory Verbal Learning Task, Trail Making Tests A and B, Grooved Pegboard); +, comparable tests were used; -, tests were not comparable with core battery.

*Five different definitions were used. The percentages given are for $1 \mathrm{SD}$ decline in one or more tests.

$\dagger$ Analyzed per domain.

$\$$ Three different definitions were used on two tests. Proportions of patients with deficit varied from $7 \%$ to $33 \%$.

Neuropsychologic test batteries were rated with respect to (1) the cognitive domain of the tests, (2) the sensitivity of the tests, (3) the availability of parallel forms of the tests, and (4) the overall balance of the cognitive domains assessed in the battery. So that the comparability of the studies could be further improved, (5) a recommended core battery was taken as the basis for our assessment of quality of the test batteries used. This core battery minimally includes the Rey Auditory Verbal Learning Task, the Trail Making Tests A and B, and the Grooved Pegboard. These tests are widely used, easy to conduct, well-normalized, and sensitive to cerebral damage.

Analysis. Studies were classified as (1) cohort studies, aiming to determine the incidence of cognitive decline at a certain moment after the operation and/or to identify determinants of cognitive decline, or (2) intervention (controlled) studies, investigating the cerebral protective effect of intraoperative interventions.

To determine whether a pooled analysis could be carried out, we assessed the comparability of the studies entered into the review in terms of precise timing of neuropsychologic testing, comparability of tests, and definition of decline.

\section{Results}

Cohort studies. The twelve cohort studies meeting the selection criteria are presented in Table II. Some of these studies exclusively aimed to determine the incidence of neuropsychologic decline, whereas others were designed to identify determinants of cognitive decline. The studies in Table II are ordered by year of publication. The mean age of the patients studied increased over time, but no clear time trend could be observed in the incidences of cognitive deficits, which varied from $4 \%$ to $47 \%$.

None of the studies designed as a correlation study $21,25,26,28,31$ was able to identify determinants of cognitive decline in the primary analysis. However, in a multivariate analysis, Tardiff and associates ${ }^{26}$ found a significant association between short-term memory dysfunction after $\mathrm{CABG}$ and a variant form of the apolipoprotein $\mathrm{E}$ gene, especially in patients with lower educational levels. This gene encodes the APOE protein, which is responsible for repair of neuronal injury and probably involved in the development of Alzheimer disease.

Intervention studies. The eleven intervention studies included are shown in Table III. Ten of them were randomized trials. In two studies, the initial data analysis demonstrated that the intervention studied led to a statistically significantly $(P<.05)$ decreased risk of cognitive decline. Hammon and colleagues ${ }^{42}$ compared the results in patients operated on in 1991 and 1992 with results in patients operated on in the next 2 years. In the second time period, the surgical team had adopted the use of epiaortic scanning and had increased the use of the single crossclamp technique and left ventricular venting. This combined strategy reduced the incidence of cognitive decline by $11 \%(P=.01)$. The other study 
with a significant result in the initial analysis showed a beneficial effect of the use of an arterial line filter. ${ }^{35}$

Many intervention studies had insufficient statistical power to detect clinically meaningful differences. In some of these studies, post hoc use of another definition of cognitive decline led to significant results. One example is the remacemide trial by Arrowsmith and coworkers. ${ }^{33}$ Individual cognitive decline was less frequent in the treated group, but the study lacked power to reach statistical significance. Redefining cognitive decline as "overall postoperative change" made the favorable effect of remacemide statistically significant.

Pulsatile blood flow during CPB did not improve neurocognitive outcome in 316 patients, ${ }^{36}$ but in the same series, alpha-stat blood gas management reduced the incidence of cognitive deficits. This reduction was significant in patients with a bypass time of more than 90 minutes. The protective effect of alpha-stat blood gas management was also found by Patel and associates. ${ }^{37}$ The observed difference became statistically significant when a more stringent definition of neuropsychologic deficit (decline on three tests instead of two tests) was used.

The three studies on the influence of perfusion temperature ${ }^{39-41}$ failed to demonstrate a clear advantage of hypothermia compared with normothermia, but the sample sizes of the studies were relatively small, and in the study of Heyer and colleagues ${ }^{41}$ only $26 \%$ of the study patients were available for follow-up.

Neuropsychology. The selected studies included neuropsychologic tests as the measure of cognitive decline. Of the 23 selected studies, six included the core battery as recommended by the Statement of Consensus. ${ }^{11}$ In addition, four studies used tests similar to the recommended core battery (see Tables II and III). Accordingly, ten studies were at least partially comparable and met with widely accepted quality criteria.

Four study groups ${ }^{5,22,30,37}$ used several definitions of cognitive decline in their samples. The definition used most frequently (in nine studies) was a postoperative deterioration of at least 1 standard deviation (of the population's performance at baseline) compared with preoperative testing in at least two tests. In one study the same definition was used with a minimum of three tests showing deterioration, whereas one other study took deterioration in one test as criterion. Comparability in terms of definition of cognitive decline was thus limited to nine studies.

Pooled analysis. Four cohort studies ${ }^{23-25,28}$ and two intervention studies ${ }^{33,35}$ were comparable not only in definition of decline and use of the core battery or com- parable tests, but also in timing of test administration. These six studies in total included 505 patients, of whom 448 completed 2 months of follow-up (Table IV). We combined the results of these studies in a weighted average (the sum of the proportions of patients with cognitive decline per study times number of patients per study, divided by the total number of patients). For the two intervention studies, the weighted mean of the two treatment groups was used. On average, $22.5 \%$ of the CABG patients had a decline of at least 1 standard deviation in at least two of a total of nine or ten tests 2 months after their operation $(P<.0001 ; 95 \%$ confidence interval, $18.7 \%-26.4 \%)$.

\section{Discussion}

This study systematically reviewed reports on cognitive decline after CABG. The literature search was extensive. In an attempt to select studies that could be compared, we formulated stringent selection criteria. A limitation of using these selection criteria is that some informative aspects of research were rejected. The relatively small number of the studies that could be included in the review underlines the lack of comparability of studies carried out until now.

The reported incidences of cognitive deficits varied widely. At least in part, this can be explained by the differences in timing of test administration and definitions of cognitive deficit. A high loss to follow-up in 3 studies $^{5,24,41}$ may also have influenced the incidences found, as loss to follow-up is seldom random. ${ }^{6}$ Most of the included studies were comparable in terms of neuropsychologic tests used, which is probably encouraged by the Statement of Consensus that was held in 1994. ${ }^{11}$

Within the six studies used for the pooled analysis, there was still a considerable variation in the reported incidence of cognitive decline (10\%-38\% 2 months after the operation). It is not possible to conclude from these studies that the incidence of cognitive deficits has decreased in the past 10 years. Improved outcome as a result of better anesthesiologic and perfusion management may be offset by the increasing age of the patients, which in itself is associated with an increased risk for cerebral complications. ${ }^{36,42}$ With the six selected studies, we calculated an average incidence of cognitive deficits of $22.5 \% 2$ months after CABG. This figure must be interpreted with caution because, even within these six studies, methodologic differences were present. For example, the cutoff value of 1 standard deviation, used to define a deficit, varied per study, because the baseline performances of the six patient series are inevitably not the same. A formal metaanalysis, which is typically performed with a series of 
Table III. Intervention studies

\begin{tabular}{|c|c|c|c|c|c|c|}
\hline $\begin{array}{l}\text { First } \\
\text { author }\end{array}$ & $\begin{array}{c}\text { Year of } \\
\text { publication }\end{array}$ & $\begin{array}{l}\text { No. of } \\
\text { patients }\end{array}$ & $\begin{array}{l}\text { Mean } \\
\text { age }(y)\end{array}$ & $\begin{array}{c}\text { NP-test } \\
\text { timing (mo) }\end{array}$ & $\begin{array}{c}\text { Lost to } \\
\text { follow-up }(\%)\end{array}$ & $\begin{array}{l}\text { No. of } \\
\text { tests used }\end{array}$ \\
\hline Fish $^{32}$ & 1987 & $2 \times 50$ & 58 & 2 & 26 & 10 \\
\hline Arrowsmith ${ }^{33}$ & 1998 & $87+84$ & 59 & 2 & 7 & 9 \\
\hline Sellman ${ }^{34}$ & 1993 & $3 \times 20$ & 59 & $1 / 6$ & 10 & 13 \\
\hline Pugsley ${ }^{35}$ & 1994 & $53+52$ & 55 & 2 & 5 & 10 \\
\hline Murkin $^{36}$ & 1995 & $4 \times 79$ & 61 & 2 & 24 & 5 \\
\hline Patel $^{37}$ & 1996 & $2 \times 35$ & 57 & 1.5 & 0 & 10 \\
\hline Gold $^{38}$ & 1995 & $2 \times 124$ & 66 & 6 & 9 & 11 \\
\hline Mora $^{39}$ & 1996 & $54+55$ & 63 & 1.5 & 23 & 5 \\
\hline Regragui $^{40}$ & 1996 & $31+36+29$ & 59 & 1.5 & 27 & 7 \\
\hline Heyer $^{41}$ & 1997 & $46+53$ & 64 & 1.5 & 74 & 5 \\
\hline Hammon $^{42}$ & 1997 & $192+203$ & 61 & 1.5 & $?$ & 11 \\
\hline
\end{tabular}

NP-test timing, Time between CABG and postoperative neuropsychologic test administration; Definition of cognitive deficit: 1 ( $\geq 1$ SD in $\geq 1$ test); 2 ( $\geq 1$ SD in $\geq 2$ tests); 3 ( $\geq 1$ SD in $\geq 3$ tests); 4 ( $\geq 0.5$ SD in a domain); 5 ( $\geq 20 \%$ in $\geq 2$ tests); 6 ( $\geq 20 \%$ in $\geq 20 \%$ ); 7 (other); Comparability: ++ , tests of "core battery" are used (Rey Auditory Verbal Learning Task, Trail Making Tests A and B, Grooved Pegboard); +, comparable tests were used; -, tests were not comparable with core battery.

Table IV. The four cohort studies and two intervention studies that were comparable

\begin{tabular}{|c|c|c|c|c|c|c|c|}
\hline $\begin{array}{l}\text { First } \\
\text { author }\end{array}$ & $\begin{array}{c}\text { Year of } \\
\text { publication }\end{array}$ & $\begin{array}{c}\text { No. of } \\
\text { patients }\end{array}$ & $\begin{array}{l}\text { Mean } \\
\text { age } \\
(y)\end{array}$ & $\begin{array}{c}\text { NP-test } \\
\text { timing } \\
(\text { mo })\end{array}$ & $\begin{array}{c}\text { No. of } \\
\text { tests } \\
\text { used }\end{array}$ & $\begin{array}{c}\text { No. of patients } \\
\text { who completed } \\
\text { follow-up }\end{array}$ & $\begin{array}{c}\text { Proportion of } \\
\text { patients with } \\
\text { cognitive deficit }(\%)\end{array}$ \\
\hline Treasure $^{23}$ & 1989 & 76 & 55 & 2 & 10 & 67 & 37 \\
\hline Harrison $^{24}$ & 1989 & 78 & 55 & 2 & 10 & 47 & 36 \\
\hline Pugsley $35 *$ & 1994 & 105 & 55 & 2 & 10 & 100 & $17.45^{*}$ \\
\hline Toner $^{25}$ & 1996 & 61 & 60 & 2 & 10 & 61 & 38 \\
\hline Arrowsmith $^{33 *}$ & 1998 & 171 & 59 & 2 & 9 & 159 & $10.45^{*}$ \\
\hline Braekken $^{28}$ & 1998 & 14 & 64 & 2 & 10 & 14 & 14 \\
\hline Total & & 505 & & & & 448 & \\
\hline Weighted average & & & & & & & 22.5 \\
\hline
\end{tabular}

The four cohort studies and two intervention studies that were comparable in definition of cognitive decline (a decline in performance at least 1 standard deviation in at least two tests), use of the core battery (Rey Auditory Verbal Learning Task, the Trail Making Tests A and B, and the Grooved Pegboard) or comparable neuropsychologic tests, and timing of test administration ( 2 months after operation). These six studies include 505 patients, of whom 448 completed 2 months of followup. To calculate a weighted average, the proportion of patients with cognitive decline per study was multiplied with the number of patients per study who completed follow-up. The sum of the multiplications was then divided by the total number of patients who completed follow-up. On average, the proportion of patients with cognitive decline was $22.5 \%$ ( $P<.0001 ; 95 \%$ confidence interval, $18.7 \%-26.4 \%)$.

* Intervention studies, in which the weighted mean of the proportions of patients with a deficit in the two treatment groups was used.

methodologically comparable randomized trials, includes the use of more advanced weighing factors, testing of homogeneity of the effect estimates of the different studies, and a sensitivity analysis. However, the methodology of meta-analysis of uncontrolled observational studies is subject to debate, ${ }^{43}$ and its use in this review would have unjustly suggested a high level of objectiveness and precision.
The clinical meaning of a decline of 1 standard deviation in two tests is relative, because the figure calculated, $22.5 \%$, does not indicate the percentage of patients who are significantly disabled after CABG. Several authors emphasize that, in most patients, the deficit does not matter to the patient in functional terms. Apparently, many activities of daily life do not require the level of performance called for during neuropsychologic testing. 


\begin{tabular}{|c|c|c|c|}
\hline $\begin{array}{l}\text { Definition of } \\
\text { cognitive deficit }\end{array}$ & Comparability & Intervention studied & Results \\
\hline 7 & - & Prostacyclin during CPB & $0 \%$ cognitive decline in intervention group and control group \\
\hline 2 & + & Remacemide vs placebo & $\begin{array}{l}\text { Remacemide group: } 9 \% \text { decline; placebo group: } 12 \% \text { decline } \\
(P=.6)\end{array}$ \\
\hline 2 & - & $\begin{array}{l}\text { Membrane vs bubble oxygenator and } \\
\text { use of arterial line filter }\end{array}$ & $\begin{array}{l}\text { Bubble ox, no filter: } 24 \% / 12 \% \text { decline; bubble ox, with filter: } \\
12 \% / 6 \% \text { decline; membrane ox, no filter: } \\
15 \% / 5 \% \text { decline. All differences NS }\end{array}$ \\
\hline 2 & ++ & Use of arterial filter & Filter group: $8.2 \%$ decline; control group: $26.7 \%$ decline $(P<.03)$ \\
\hline 7 & - & $\begin{array}{l}\text { Alpha-stat vs pH-stat blood gas } \\
\text { management and pulsatile vs nonpulsatile } \\
\text { CPB }\end{array}$ & $\begin{array}{l}\text { Alpha-stat group: } 30 \% \text { cognitive dysfunction; } \\
\text { pH-stat group: } 36 \% \text { cognitive dysfunction } \\
\text { (NS); pulsatility has no effect on outcome }\end{array}$ \\
\hline 2 & ++ & $\begin{array}{l}\text { Alpha-stat vs pH-stat blood gas } \\
\text { management }\end{array}$ & $\begin{array}{l}\text { Alpha-stat group: } 45.7 \% \mathrm{np} \text { deficit; } \\
\text { pH-stat group: } 68.6 \% \mathrm{np} \text { deficit (NS) }\end{array}$ \\
\hline 7 & - & $\begin{array}{l}\text { Blood pressure during CPB: } 50-60 \mathrm{~mm} \\
\mathrm{Hg} \text { vs } 80-100 \mathrm{~mm} \mathrm{Hg}\end{array}$ & $\begin{array}{l}\text { Low pressure group: } 12 \% \text { deteriorated; } \\
\text { high pressure group: } 11 \% \text { deteriorated (NS) }\end{array}$ \\
\hline 1 & - & Perfusion temperature $<28^{\circ} \mathrm{C}$ vs $>35^{\circ} \mathrm{C}$ & $15 \%$ deterioration in both treatment groups \\
\hline 7 & - & $\begin{array}{l}\text { Perfusion temperature } 28^{\circ} \mathrm{C} \text { vs } 32^{\circ} \mathrm{C} \\
\text { vs } 37^{\circ} \mathrm{C}\end{array}$ & $\begin{array}{l}\text { Significantly more deterioration in } 37^{\circ} \mathrm{C} \text { group than compared } \\
\text { to } 32^{\circ} \mathrm{C} \text { group }(P=.015)\end{array}$ \\
\hline 7 & + & Perfusion temperature $28^{\circ} \mathrm{C}$ vs $34^{\circ} \mathrm{C}$ & $\begin{array}{l}15 \% \text { decline in } 28^{\circ} \mathrm{C} \text { group; } 39 \% \text { decline in } 34^{\circ} \mathrm{C} \text { group; } \\
\text { difference NS }\end{array}$ \\
\hline 5 & ++ & $\begin{array}{l}\text { Combination of epiaortic scanning, } \\
\text { more use of single crossclamp and more } \\
\text { ventricular venting vs standard treatment }\end{array}$ & $\begin{array}{l}\text { Intervention group: } 18 \% \text { decline; standard treatment group: } \\
29 \% \text { decline }(P=.01) \text { (nonrandomized study) }\end{array}$ \\
\hline
\end{tabular}

However, a small proportion of patients with intellectual dysfunction or memory deficits become sufficiently disabled to prevent return to employment. ${ }^{1,22}$

The discrepancy between decline in test performance and functional decline is also expressed by the methodologic difficulties of defining a cognitive deficit. Mahanna and colleagues ${ }^{5}$ demonstrated the enormous influence of the definition of cognitive deficit that is chosen by applying five different definitions on the same patient sample. Depending on the definition used, the incidence of cognitive deficit ranged from $1.1 \%$ to $34 \%$ at 6 weeks and from $3.4 \%$ to $19.4 \%$ at 6 months postoperatively.

Most authors defined deficit as a certain deterioration in one or more tests, which may seem accurate. However, some tests comprise more than one test variable, and from most studies it was not clear whether test deficit meant deterioration in one or all of the variables of one test. This obviously creates a multitude of possible outcomes and is therefore a factor complicating the interpretation of the incidence data. A deterioration of 1 standard deviation in postoperative functioning compared with preoperative functioning was the most frequently used cutoff value. This is arbitrary and does not necessarily reveal real cognitive change, since it does not take into account the reliability of the change scores. Practice effects were almost always mentioned but not included in analyses, which may have resulted in an underestimation of incidence figures. There is emerging recognition of the importance of defining real change in test-retest scores as opposed to artifactual change resulting from low test reliability and susceptibility to practice effects. Recent research is increasingly focused on the use of reliable change indices. These indices define the range in which an individual score is likely to fluctuate because of the imprecision of the measure, providing statistically based cutoff scores for cognitive change on each measure. ${ }^{44,45}$ For example, a $90 \%$ reliable change interval is calculated on the basis of the correlation and the standard error of the difference between baseline and follow-up scores of control subjects. When the difference between an individual patient's postoperative and preoperative scores falls outside this interval, he or she is considered to have a statistically significant change in performance on this particular neuropsychologic measure. ${ }^{44}$

The single-case analysis technique, recommended in the consensus statements, ${ }^{11,46}$ uses the patient as his or her own control and defines a cognitive deficit as a $20 \%$ decrease in at least $20 \%$ of the tests. This method also has some drawbacks. In the first place, reducing the continuous test scores to a dichotomous outcome measure (presence of a $20 \%$ decrease or not) is a "costly" way of data handling that reduces statistical power and may have made several randomized studies fail to 
reach statistically significant results. The $20 \%$ decrease rule is as arbitrary as the 1 standard deviation decrease rule. The problem may be overcome by refraining from "dichotomizing" data and just calculating how much the patient's performance deviates from the expected (baseline or control group) performance. Second, due to floor effects it may be difficult to demonstrate a deficit in patients with a low preoperative test performance. In the third place, as demonstrated by Browne and colleagues, ${ }^{30}$ "regression toward the mean" may strongly influence single-case definitions of cognitive deterioration. High baseline performers may be wrongly classified as impaired and low baseline performers may not show a deficit although deterioration had actually occurred. This problem can be overcome by using group mean analysis, which is free from the influence of regression to the mean (in contrast to analysis by single-case definitions). As discussed before, comparison of mean group performance before and after surgery does have disadvantages, especially if large practice effects are present. However, if a suitable control group is available (randomized trial), comparison of group means allows for the control of both practice effects and regression to the mean.

\section{Conclusions}

A pooled analysis of six highly comparable studies yielded a proportion of $22.5 \%$ of patients with a cognitive deficit 2 months after CABG. Although this percentage is partly determined by the definition of cognitive deficit that was used, it demonstrates that cognitive dysfunction is a frequently occurring complication of CABG. The etiologic contribution of CPB to this complication will remain unclear until a randomized trial that directly compares off-pump CABG with on-pump CABG is carried out. To improve comparability of future studies, we advocate that researchers use the guidelines of the 1994 consensus meeting. However, the recommended single-case analysis technique has some drawbacks and may be replaced by other analysis techniques, especially when a control group is included in the study design.

We thank Professor D. E. Grobbee, Professor C. J. Kalkman, Professor R. S. Kahn, and Doctor E. Buskens for revising the manuscript.

\section{REFERENCES}

1. Roach GW, Kanchuger M, Mangano CM, Newman M, Nussmeier N, Wolman R, et al. Adverse cerebral outcomes after coronary bypass surgery. Multicenter Study of Perioperative Ischemia Research Group and the Ischemia Research and
Education Foundation Investigators. $\mathrm{N}$ Engl $\mathrm{J}$ Med 1996;335:1857-63.

2. Newman MF, Wolman R, Kanchuger M, Marschall K, MoraMangano C, Roach G, et al. Multicenter preoperative stroke risk index for patients undergoing coronary artery bypass graft surgery. Circulation 1996;94(Suppl):II-74-80.

3. Mills SA. Risk factors for cerebral injury and cardiac surgery. Ann Thorac Surg 1995;59:1296-9.

4. Tuman KJ, McCarthy RJ, Najafi H, Ivankovich AD. Differential effects of advanced age on neurologic and cardiac risks of coronary artery operations. J Thorac Cardiovasc Surg 1992;104:1510-7.

5. Mahanna EP, Blumenthal JA, White WD, Croughwell ND, Clancy CP, Smith LR, et al. Defining neuropsychological dysfunction after coronary artery bypass grafting. Ann Thorac Surg 1996;61:1342-7.

6. Blumenthal JA, Mahanna EP, Madden DJ, White WD, Croughwell ND, Newman MF. Methodological issues in the assessment of neuropsychologic function after cardiac surgery. Ann Thorac Surg 1995;59:1345-50.

7. Benedict RH. Cognitive function after open-heart surgery: Are postoperative neuropsychological deficits caused by cardiopulmonary bypass? Neuropsychol Rev 1994;4:223-55.

8. Robin ED, McCauley RF, Notkin H. Long-term cognitive abnormalities associated with cardiopulmonary bypass (CPB) and the Babel effect. Chest 1994;106:278-81.

9. Gill R, Murkin JM. Neuropsychologic dysfunction after cardiac surgery: What is the problem? J Cardiothorac Vasc Anesth 1996;10:91-8.

10. Borowicz LM, Goldsborough MA, Selnes OA, McKhann GM. Neuropsychologic change after cardiac surgery: a critical review. J Cardiothorac Vasc Anesth 1996;10:105-11.

11. Murkin JM, Newman SP, Stump DA, Blumenthal JA. Statement of consensus on assessment of neurobehavioral outcomes after cardiac surgery. Ann Thorac Surg 1995;59:1289-95.

12. Smith PL, Taylor KM, editors. Cardiac surgery and the brain. Sevenoaks, Great Britain: Hodder and Stoughton Publishers; 1993.

13. Taylor KM. Brain damage during cardiopulmonary bypass. Ann Thorac Surg 1998;65:S20-6.

14. Venn GE, Patel RL, Chambers DJ. Cardiopulmonary bypass: perioperative cerebral blood flow and postoperative cognitive deficit. Ann Thorac Surg 1995;59:1331-5.

15. Patel RL, Turtle MR, Chambers DJ, Newman S, Venn GE. Hyperperfusion and cerebral dysfunction: effect of differing acidbase management during cardiopulmonary bypass. Eur J Cardiothorac Surg 1993;7:457-63.

16. Toner I, Taylor KM, Lockwood G, Newman S, Smith PL. EEG changes during cardiopulmonary bypass surgery and postoperative neuropsychological deficit: the effect of bubble and membrane oxygenators. Eur J Cardiothorac Surg 1997;11:312-9.

17. McKhann GM, Borowicz LM, Goldsborough MA, Enger C, Selnes OA. Depression and cognitive decline after coronary artery bypass grafting. Lancet 1997;349:1282-4.

18. Smith PL, Treasure T, Newman SP, Joseph P, Ell PJ, Schneidau A, et al. Cerebral consequences of cardiopulmonary bypass. Lancet 1986;1:823-5.

19. Selnes OA, Goldsborough MA, Borowicz LM, Enger C, Quaskey SA, McKhann, GM. Determinants of cognitive change after coronary artery bypass surgery: a multifactorial problem. Ann Thorac Surg 1999;67:1669-76. 
20. Toner I, Taylor KM, Newman S, Smith PL. Cerebral functional changes following cardiac surgery: neuropsychological and EEG assessment. Eur J Cardiothorac Surg 1998;13:13-20.

21. Ellis RJ, Wisniewski A, Potts R, Calhoun C, Loucks P, Wells MR Reduction of flow rate and arterial pressure at moderate hypothermia does not result in cerebral dysfunction. J Thorac Cardiovasc Surg 1980;79:173-80.

22. Shaw PJ, Bates D, Cartlidge NE, French JM, Heaviside D, Julian DG, et al. Long-term intellectual dysfunction following coronary artery bypass graft surgery: a six month follow-up study. Q J Med 1987;62:259-68.

23. Treasure T, Smith PL, Newman S, Schneidau A, Joseph P, Ell P, et al. Impairment of cerebral function following cardiac and other major surgery. Eur J Cardiothorac Surg 1989;3:216-21.

24. Harrison MJ, Schneidau A, Ho R, Smith PL, Newman S, Treasure T. Cerebrovascular disease and functional outcome after coronary artery bypass surgery. Stroke 1989;20:235-7.

25. Toner I, Taylor KM, Newman S, Smith PL. Cerebral functional deficit in cardiac surgical patients investigated with p300 and neuropsychological tests. Electroencephalogr Clin Neurophysiol Suppl 1996;46:243-51.

26. Tardiff BE, Newman MF, Saunders AM, Strittmatter WJ, Blumenthal JA, White WD, et al. Preliminary report of a genetic basis for cognitive decline after cardiac operations. The Neurologic Outcome Research Group of the Duke Heart Center. Ann Thorac Surg 1997;64:715-20.

27. McKhann GM, Goldsborough MA, Borowicz LM Jr, Selnes OA, Mellits ED, Enger C, et al. Cognitive outcome after coronary artery bypass: a one-year prospective study. Ann Thorac Surg 1997;63:510-5

28. Braekken SK, Reinvang I, Russell D, Brucher R, Svennevig JL. Association between intraoperative cerebral microembolic signals and postoperative neuropsychological deficit: comparison between patients with cardiac valve replacement and patients with coronary artery bypass grafting. J Neurol Neurosurg Psychiatry 1998;65:573-6.

29. Vanninen R, Aikia M, Kononen M, Partanen K, Tulla H, Hartikainen P, et al. Subclinical cerebral complications after coronary artery bypass grafting: prospective analysis with magnetic resonance imaging, quantitative electroencephalography, and neuropsychological assessment. Arch Neurol 1998;55:618-27.

30. Browne SM, Halligan PW, Wade DT, Taggart DP. Cognitive performance after cardiac operation: implications of regression toward the mean. J Thorac Cardiovasc Surg 1999;117:481-5.

31. Rasmussen LS, Christiansen M, Hansen PB, Moller JT. Do blood levels of neuron-specific enolase and S-100 protein reflect cognitive dysfunction after coronary artery bypass? Acta Anesthesiol Scand 1999;43:495-500.

32. Fish KJ, Helms KN, Sarnquist FH, van Steennis C, Linet OI, Hilberman $\mathrm{M}$, et al. A prospective, randomized study of the effects of prostacyclin on neuropsychologic dysfunction after coronary artery operation. J Thorac Cardiovasc Surg 1987;93:609-15.

33. Arrowsmith JE, Harrison MJ, Newman SP, Stygall J, Timberlake
N, Pugsley WB. Neuroprotection of the brain during cardiopulmonary bypass: a randomized trial of remacemide during coronary artery bypass in 171 patients. Stroke 1998;29:2357-62.

34. Sellman M, Holm L, Ivert T, Semb BK. A randomized study of neuropsychological function in patients undergoing coronary bypass surgery. Thorac Cardiovasc Surg 1993;41:349-54.

35. Pugsley W, Klinger L, Paschalis C, Treasure T, Harrison M, Newman S. The impact of microemboli during cardiopulmonary bypass on neuropsychological functioning. Stroke 1994;25:1393-9.

36. Murkin JM, Martzke JS, Buchan AM, Bentley C, Wong CJ. A randomized study of the influence of perfusion technique and $\mathrm{pH}$ management strategy in 316 patients undergoing coronary artery bypass surgery. J Thorac Cardiovasc Surg 1995;110:349-62.

37. Patel RL, Turtle MR, Chambers DJ, James DN, Newman S, Venn GE. Alpha-stat acid-base regulation during cardiopulmonary bypass improves neuropsychologic outcome in patients undergoing coronary artery bypass grafting. J Thorac Cardiovasc Surg 1996;111:1267-79.

38. Gold JP, Charlson ME, Williams RP, Szatrowski TP, Peterson JC, Pirraglia PA, et al. Improvement of outcomes after coronary artery bypass: a randomized trial comparing intraoperative high versus low mean arterial pressure. J Thorac Cardiovasc Surg 1995;110:1302-11.

39. Mora CT, Henson MB, Weintraub WS, Murkin JM, Martin TD, Craver JM, et al. The effect of temperature management during cardiopulmonary bypass on neurologic and neuropsychologic outcomes in patients undergoing coronary revascularization. J Thorac Cardiovasc Surg 1996;112:514-22.

40. Regragui I, Birdi I, Izzat MB, Black AM, Lopatatzidis A, Day C, et al. The effects of cardiopulmonary bypass temperature on neuropsychologic outcome after coronary artery operations: a prospective randomized trial. J Thorac Cardiovasc Surg 1996;112:1036-45.

41. Heyer EJ, Adams DC, Delphin E, McMahon DJ, Steneck SD, Oz $\mathrm{MC}$, et al. Cerebral dysfunction after coronary artery bypass grafting done with mild or moderate hypothermia. J Thorac Cardiovasc Surg 1997;114:270-7.

42. Hammon JW Jr, Stump DA, Kon ND, Cordell AR, Hudspeth AS, Oaks TE, et al. Risk factors and solutions for the development of neurobehavioral changes after coronary artery bypass grafting. Ann Thorac Surg 1997;63:1613-8.

43. Egger M, Schneider M, Davey Smith G. Spurious precision? Meta-analysis of observational studies. BMJ 1998;316:140-4.

44. Kneebone AC, Andrew MJ, Baker RA, Knight JL. Neuropsychologic changes after coronary artery bypass grafting: use of reliable change indices. Ann Thorac Surg 1998;65:1320-5.

45. Bruggemans EF, Van de Vijver FJ, Huysmans HA. Assessment of cognitive deterioration in individual patients following cardiac surgery: correcting for measurement error and practice effects. $\mathbf{J}$ Clin Exp Neuropsychol 1997;19:543-59.

46. Murkin JM, Stump DA, Blumenthal JA, McKhann G. Defining dysfunction: group means versus incidence analysis-a statement of consensus. Ann Thorac Surg 1997;64:904-5. 